\title{
Public Policy Analysis: Problem Exploration and Recommendation to Public Service Innovation in Surakarta City Government
}

\author{
R. Slamet Santoso ${ }^{1}$, Dewi Rostyaningsih ${ }^{2}$, Hesti Lestari $^{3}$ \\ \{rssantoso@lecturer.undip.ac.id ${ }^{1}$ \} \\ Universitas Diponegoro, Indonesia ${ }^{1,2,3}$
}

\begin{abstract}
The bureaucracy has an important role in improving people's welfare, through the implementation of various public services. This study aims to analyze the policy of developing public service innovation in the Surakarta City Government, from problem identification to formulation of recommendations. The theory used is public policy analysis from E.S. Quade, using descriptive qualitative research methods, with data obtained from interviews, observations, and documentation. The results show the best alternatives: 1) Institutional and institutional arrangements that are capable of developing public service innovation, 2) Optimizing the implementation of public service innovation development policies (status quo), and 3) Developing cultural value change management in line with the development of public service innovation. Strategic recommendations for implementing the chosen alternatives are: 1) Establishing regulations for the development of innovation models; 2) Institutionalizing the development of public service innovations supported by authorities and resources; 3 ) Increase leadership commitment and appreciation to increase public service innovation; and 4) Build cooperation networks for the development of public service innovations. The implication of further research is to explore the leadership's commitment which is very important in the development of innovation in local government.
\end{abstract}

Keywords: Policy Analysis, Problem, Solutions, Public Policy, Innovation

\section{Introduction}

Nowadays, innovation has become the forefront effort for the government to improve the public service sector. Amidst of disruption era and VUCA (volatility, uncertainty, complexity, and ambiguity), the entire disruptions change human's landscape on how we think, act, and feel. It makes a substantial implication in the government sector, public administration, and public services.

The government has realized that they need to adjust and adapt to the changes by making some innovations. Over the past five years, innovation has become the primary focus to be implemented in both the central government and the regional government. The influx of innovations in every government sector has benefited stakeholders in solving their problems and gaining more value-added.

The spirit of innovation has been spread out in government, ministries, non-ministerial government agencies, regional government, etc. Meanwhile, President Joko Widodo was also profoundly committed through Law Number 38 of 2017 on Regional Innovation to encourage the creation of innovations at the regional level. On the other hand, President also signed 
President Decree Number 74 of 2019 to form the National Research and Innovation Bodies (BRIN).

The commitment of the government to innovation creation also can be seen throughout innovation competition. Two ministries run the competition, the Ministry of Administrative and Bureaucratic Reform through Public Service Innovation Competition (KIPP) and Ministry of Home Affairs through Innovative Government Award (IGA), which will produce many innovation proposals.

Said [1] states several constraints in the innovation development process. Firstly, the major constraint of innovation development is to start from where, who, and when the innovation is developed. Secondly, the lack of political, budget, and technical support. Third, the lack of cooperation between leaders, stakeholders, and citizens. Fourth, the lack of adequate public service-oriented, and fifth, the administrative and personnel system that need to be well improved [2].

Several experts have studied the research about innovation. Capuno [3] researched about the importance of regional government as the innovation leading mover in regions [2]. Pekkarinen et al. [4] state several substantial pressures affect and bring some clashes between the new and existing paradigm [5].

Nevertheless, these clashes will become a fundamental basis to analyze the needs of innovation. Hennala et al. [6] analyzed some public innovations involving multi-actors using the innovation concept, public organization, and stakeholders through a constructive research approach and combining quantitative and qualitative analysis models on innovation ${ }^{[4]}$.

Putri and Pambudi [5] find that the birth certificate service through e-government has not been optimal, proved by (1) low participation rate, (2) over-innovation, (3) lack of resources, (4) partial services, (5) the lack of information in society. Yohanitas [7] states that Surakarta City has been successful in developing innovations to become such an attractiveness in each period of its regional leadership. The emergence of brand-new programs proves this phenomenon. On the one hand, the implementation of innovation should not be seen just as its quantity, but should continuously solve the problems in public [8].

This research will unveil the empirical model and recommendation model of the capacity of public service innovation in the Surakarta City Government.

\section{Literature Review}

\subsection{Policy Analysis}

Ericson in Wahab [9] explains that public policy analysis is a future-oriented investigation using an optimal resource to achieve a set of desired goals.

Kent in Wahab [9] explains that public policy is a systematic, disciplined, analytical, intelligent, and creative study conducted to produce reliable recommendations in the form of actions in solving concrete political problems [2].

Dunn [10] looks at the public policy as an activity to create knowledge about "why" and "how" the policymaking process is going as it should. More clearly, Nugroho [11] states that policy analysis is an intellectual and practical analysis to create (critically) and communicate the knowledge about "why" and "how" the policy can be made and exist. 


\subsection{Innovation and Public Administration}

According to a United Nations publication through the Department of Economic and Social Affairs (UNDESA), it generally explains that government innovation is such a creative idea that will solve the public problems once it can be well implemented. Principally, these kinds of innovations include new products, new policies and programs, new approaches, and new processes. It also emphasizes that managerial innovation in the public sector can be defined as a development or brand-new design in policy and SOP by the public organization to resolve their problems.

According to UNDESA [2], innovation in public administration can be divided into several types: (1) Institutional innovations, which is focusing on the renewal of established institutions or creating new institutions; (2) Organizational innovation, which tends to introduce new management procedures and techniques in public administration; (3) Process innovation, which is focusing on the quality development of public services; and (4) Conceptual innovation, which is directed to introduce the new form of governance.

\subsection{Public Service}

Public service is an activity that becomes the obligation of the government to run its governance. According to Supriyatna in Anggara [8], the more advanced the community, the more efficient service is needed and calculated with economic value and ensuring certainty. Moenir in Anggara [8] explains that service is a process of fulfillment of needs through the activities of others.

Thoha in Anggara [8] explains that public service is an effort made by a particular person/group of people/institutions to provide ease of assistance to the community to achieve specific goals. The leading institution that plays a role in providing public service is the government bureaucracy.

To drive the public service, the government refers to the Law Number 25 of 2009 on Public Service. According to this law, the term of Public Service is emphasized as an activity to fulfill the public needs according to the existing law/regulation to all the citizens through administrative service and public goods fulfillment provided by public service operators.

\section{Method}

The research method used is a qualitative type alongside the presentation of field-research results through data collection by conducting in-depth interviews with people who are being the research subject. This research/research informant's subjects are the innovators and leaders in the Regional Apparatus Organization (OPD) in Surakarta City Government.

The informant's selection process begins with determining a "key informant" that has been purposively selected by particular characteristics to obtain comprehensive data and factual information in this research process. Furtherly, the research process continues to roll like a snowball. 


\section{Result and Discussion}

\subsection{Innovation in Surakarta City Government}

The existing innovation in Surakarta City Government is being handled by two Regional Apparatus Organization (OPD), including the Research and Development Section of the Regional Planning and Development Agency (Litbang Bappeda) and the Organizational Agency of Regional Secretariat (Bagian Organisasi Sekretariat Daerah). The Regional Secretariat's Organization focuses on innovations in the public service sector while Research and Development Section of the Regional Planning and Development Agency (Litbang Bappeda) houses innovation functions. The functions of Regional Planning and Development Agency (Bappeda) is run based on Government Regulations Number 38 of 2017, where the innovation authority is run under the Research and Development section.

Based on the interview, the Research and Development Section (Litbang) has not been able to stand alone. It impacts the lack of power within the Research and Development Section (Litbang) to direct innovation creation in every Regional Apparatus Organization (OPD). Generally, innovation development in Surakarta City has been well-created. The number of innovations works present from the government, and the community tends to increase each year (figure 1).

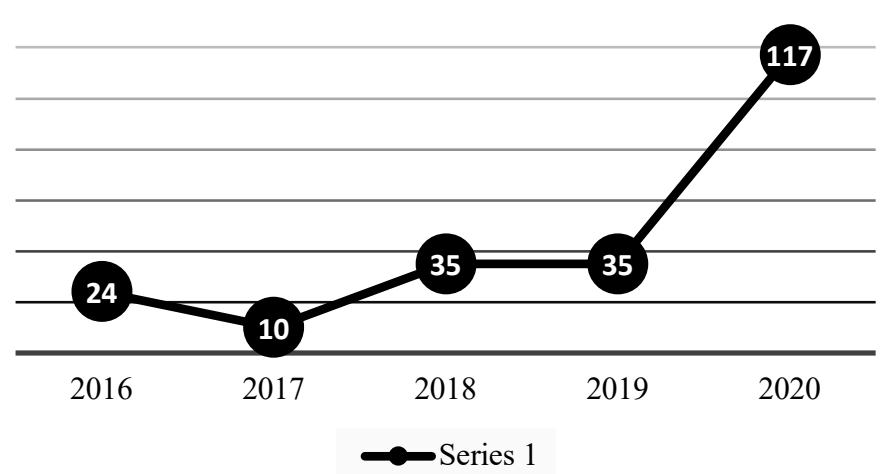

Fig. 1. Innovation is Surakarta City 2016-2020.

Source: The Organizational Section of Regional Secretariat.

The amount of innovation that works in Surakarta from 2016 to 2020 is likely to increase. In 2016, 24 innovation works, while by 2020, the number of innovation works has reached 117 innovation works or nearly five times increase from 2016. Based on the data, it can be concluded that awareness of the importance of innovation in Surakarta City is relatively high, even actors involved in innovation, not only Regional Apparatus Organization (OPD) but also from the people in Surakarta City.

Innovations in Surakarta City have also been awarded from various levels. Children Incentive Card (KIA) in 2015 became the Public Service Innovation Information System (Sinovik) national Top 25 Public Service Innovation Competition (KIPP). The innovation was even taken by the Ministry of Home Affairs to serve as a national program. Besides, innovations such as Surakarta Complaints Service Unit (ULAS) also received Top 99 National Public Service Innovation Competition (KIPP) Public Service Innovation Information System 
(Sinovik). There is also Online Destination Solo Tax Payment (EPPSON), which became the Top 10 Public Service Innovation Competition (KIPP) of Central Java (2017). Surakarta was also awarded the Innovative Government Award (IGA) in 2017-2019.

\subsection{Public Service Innovation Problem in Surakarta}

Surakarta City has managed to create many innovations in the public service sector, none other than the "DNA of innovation" embedded in every element of the Civil State Apparatus (ASN). Although it has managed to get various awards from every innovation produced, problems related to the development of public service innovation in Surakarta City were found in the speakers' interviews.

As one of the cities with a high number of innovations works, Surakarta City also has several problems related to the development of innovation in Surakarta City. Here are some problems related to innovation in Surakarta City.

\subsection{Policy and Innovation Roadmap}

In recent years, Surakarta City has produced many innovations works, even increasing five times more works from 2016-2020. However, Surakarta City likely forgot one crucial thing like bureaucracy, namely regulations/policies.

Surakarta City Government has not had any rules, whether in Local Regulations (Perda), Mayor Regulations (Perwal), or Mayor's instructions on innovation development in Surakarta City. This was found based on the results of interviews conducted by researchers with various sources related to innovation in Surakarta.

In a discussion with Regional Apparatus Organization (OPD) Innovative of Surakarta City, Arthaty (Department of Health Management Information System of Surakarta City Health Office) said, "Our problem is about regulations. There are no regulations, and we are working in the technical section - if we think of the regulations, the idea will be easily lost." Based on the statement, two things found that Surakarta City does not have any regulations related to innovation and the view that the regulations make it challenging to develop and present innovation.

The absence of innovation-related policies in Surakarta will impact the sustainability of innovation in every regional device. The legal umbrella is necessarily needed for the bureaucracy to carry out its duties and functions. Suppose the legal umbrella related to innovation development in Surakarta does not exist. In that case, it could be that innovation in Surakarta City is only temporary, depending on the Civil State Aparatus (ASN) works and also the leaders.

On the one hand, Surakarta City also does not have a specific roadmap related to the development of Surakarta development. This was found from a researcher's interview with Zainal Arifin, from the Organization of Regional Secretariat. However, a different thing was revealed by Regional Planning and Development Agency (Bappeda) who stated that the innovation roadmap of Surakarta City currently refers to Regional Innovation System (SIDA).

\subsection{Institutional Issues}

The institutional issues also cause issues related to the innovation development in Surakarta City. Recently, two OPD, the Research and Development Section (Litbang Bappeda) and the Organizational Agency of Regional Secretariat (Bagian Organisasi Secretariat Daerah), held innovation development. The authority of innovation between the two institutions 
found that there was an overlap. Zainal Arifin, part of the organization, explained more about the overlapping issues in the handling process of innovation creation in Surakarta City:

"I have to tell something. Firstly, I admit the overlapping issues under the innovation development in Surakarta City. On the other hand, we are running based on Regional Regulations Number 10 of 2016 on SLTK, afterward followed up by Mayor Regulation Number 27C of 2016 on The Functions of Regional and Local Agency. On the other hand, we realized that the Mayor Regulation (Perwali) is still overlapping and need some reviews. I always see the Mayor Regulation Number 27C of 2016 on The Functions of Regional and Local Agency to run my function. We admit that this Mayor Regulation is more related to public service. Then, there is an innovation laboratory, which the very idea of its concept is found in the organization agency. Nevertheless, there is much discussion, Regional Education and Training Civil Service Agency (BKKPD) stated that they have a workshop activity to PIM (by a proper, for instance). This is a budgeting policy, which we ask for the proper, and it is very difficult to continue due to its focus on a workshop (proper workshop)".

Despite the overlapping issues between Organizational Agency (Bagian Organisasi) and the Research and Development Section (Litbang Bappeda), the primary issue in Research and Development Section (Litbang) is about the position of Research and Development Section (Litbang) in echelon three. Ronny (Head of Sub Division of Science and Technology, Surakarta City Planning and Development Agency) explained that the position of Research and Development Section (Litbang) in echelon three affects the lack of power to rule the other Regional Apparatus Organization (OPD) to develop innovation. Thus, Research and Development Section (Litbang) can't move much related to the development of innovation in Surakarta City.

\subsection{Change Management Development}

The amount of innovation works in Surakarta is relatively high, but it can only be temporary. The problem that occurs in the implementation period process is the need for a strong commitment from regional leaders in encouraging Regional Apparatus Organization (OPD) and the community to innovate. Currently, the Mayor of Surakarta has a profound commitment to the implementation of innovation. These commitments are realized by making public services more efficient. This commitment must be followed by the commitment of OPD leaders in Surakarta. If the commitment to the implementation of innovation is only owned by the regional head, it will be a problem in the succession leader process.

The other issue is the optimization of monitoring and evaluation of innovation development. Innovation products that have been produced through governance innovation and public services have no clarity to be followed up and do not continue to the national race. Through the Community Creativity and Innovation (Krenova) program, innovation products, followed by the general public, can't be used to the maximum due to the lack of interest from private sectors to use the product. 


\section{Conclusion}

\subsection{Implication}

Innovation development in Surakarta City has gone well in general. This is evidenced by the results of innovation works that increase every year. However, the Surakarta City Government also has some issues that need to be considered so that the development of innovation in Surakarta City will run better in the future. Firstly, it is all about policy. Surakarta City Government has not yet had a legal umbrella for innovation development in Surakarta. Legal umbrellas are needed for bureaucracy so that the activity can sustainably take place. Second, the institutional issue. Recently, there is still an overlapping consensus between two innovation-handled organizations, the Research and Development Section (Litbang Bappeda) and Organizational Agency (Bagian Organisasi). On the other hand, the position of Research and Development Section (Litbang) in echelon three affects the lack of power to rule the other Regional Apparatus Organization (OPD) to develop innovation. Third, the change management can be seen within the leader's (Mayor) commitment to innovate continuously invoicing.

\subsection{Recommendation}

\subsubsection{Policy and Innovation Roadmap}

a. The Surakarta City Government immediately needs to create policies to develop innovations in Surakarta City. This is necessary so that innovation in Surakarta City runs continuously. Thus, Surakarta City can maintain its position as one of the cities that often makes interesting and disrupting innovations in the future.

b. Besides, the Surakarta City Government also needs to create an innovation roadmap in Surakarta City immediately. This is needed to direct the innovation development in Surakarta to be well-measured and run continuously.

\subsubsection{Institution}

a. Organizational Agency (Bagian Organisasi) and the Research and Development Section (Litbang Bappeda) need to cooperate to reform each agency's authority to monitor innovation development, especially in the innovation competition in Surakarta City to optimize the innovation development.

b. The Research Section (Litbang) in Surakarta City should be optimized to become Research and Development Agency in its own right. This is by the burden of jobs, personnel, and power needed by Research and Development Section (Litbang) in controlling the development of innovation in Surakarta.

\subsubsection{Change Management Development}

a. The commitment increments of every leader in the Surakarta City Government environment in the implementation of innovation so that innovation can be sustainable and not dependent on individuals personally.

b. The cooperation enhancement between government agencies, private sectors, universities, and communities should be optimized to implement public service innovation in Surakarta. 


\section{References}

[1] M. Said, "Menggagas Innovative Bureaucracy Dalam Pemerintahan Indonesia," vol. 12, no. 1, pp. 1-26, 2009.

[2] UNDESA, Innovations in Governance and Public Administration: Replicating What Works, United Nat. New York, 2006.

[3] J. J. Capuno, “econstor," no. January, 2018.

[4] S. Pekkarinen, L. Hennala, V. Harmaakorpi, and T. Tura, "Clashes as potential for innovation in public service sector reform,” Int. J. Public Sect. Manag., vol. 24, no. 6, pp. 507-532, 2011.

[5] E. K. Putri and A. Pambudi, "Inovasi Pelayanan Akta Kelahiran Melalui EGovernment di Dinas Kependudukan dan Pencatatan Sipil Kota Yogyakarta," vol. 6, no. 1, pp. 69-84, 2018.

[6] L. Hennala, P. Satu, and U. Tuomo, "Challenges of multi-actor involvement in the public sector front-end innovation processes Constructing an open innovation model for developing well-being services," Eur. J. Innov. Manag., vol. 14, no. 3, pp. 364-387, 2011.

[7] W. A. Yohanitas, "Menciptakan Good Governance Melalui Inovasi Pelayanan Publik di Kota Surakarta," vol. 12, no. 3, pp. 239-258, 2016.

[8] S. Anggara, Ilmu Administrasi Negara: Kajian Konsep, Teori, dan Fakta dalam Upaya Menciptakan Good Governance. Bandung: Pustaka Setia, 2016.

[9] S. A. Wahab, Analisis Kebijakan: Dari Formulasi ke Penyusunan Model-Model Implementasi Kebijakan Publik, Cetakan Ke. Jakarta: Sinar Grafika Offset, 2016.

[10] W. N. Dunn, Analisis Kebijakan Publik, Cetakan Ke. Yogyakarta: Gadjah Mada University Press, 2003.

[11] R. Nugroho, Public Policy. Jakarta: Elex Media Komputindo, 2009. 